Pontifícia Universidade Católica do Rio de Janeiro

\author{
A importância da logística de um \\ agronegócio no Estado do Rio de Janeiro - um \\ estudo de caso da Fazenda Ilha da Saudade
}

Felipe Peres Linhares da Fonseca e Campos

Trabalho de conclusão de curso

Departamento de Administração Graduação em Administração de empresas 
Felipe Peres Linhares da Fonseca e Campos

\section{A importância da logística de um agronegócio no Estado do Rio de Janeiro - um estudo de caso da Fazenda Ilha da \\ Saudade}

Trabalho de Conclusão de Curso, apresentado ao programa de graduação em Administração da PUC-Rio como requisito parcial para a obtenção do título de graduação em Administração. 


\section{Resumo}

Campos, Felipe. A importância da logística de um agronegócio no Estado do Rio de Janeiro. Rio de Janeiro, 2016. Trabalho de Conclusão de Curso Departamento de Administração. Pontifícia Universidade Católica do Rio de Janeiro.

Este trabalho tem o intuito de mostrar a importância de um planejamento logístico eficiente para obter melhores resultados econômicos em um agronegócio, analisando diversos fatores que influenciam o êxito do empreendimento, como por exemplo, a localização.

Para isso, elaborou-se uma pesquisa exploratória, o qual foi realizado a partir de pesquisa bibliográfica em livros, sites e revistas setoriais especializadas. Foi realizada uma entrevista em profundidade, por meio de um roteiro semiestruturado, destinado ao gestor do empreendimento rural analisado. Portanto, é um estudo de caso identificando os principais problemas enfrentados em termos de logística dentro da Fazenda estudada.

Palavras-chaves:

Planejamento logístico, eficiência, resultados econômicos, agronegócio, produtor e consumidor final.

\section{Abstract}

Campos, Felipe. The importance of logistic in an agribusiness in the State of Rio de Janeiro. Rio de Janeiro, 2016. Trabalho de Conclusão de Curso Departamento de Administração. Pontifícia Universidade Católica do Rio de Janeiro.

This final work intends to show the necessity and importance of a Logistic Planning efficient to get better economics results in an agribusiness, analyzing several factors that influence the success of the enterprise, such as location. 
For this, an exploratory research elaborated, which was carry out from bibliographical research in books, websites and specialized sectoral magazines. An in-depth interview was conducted, through a semi-structured script, aimed to the manager of the analyzed rural enterprise. Therefore, it is a case study identifying the main problems faced in terms of logistics within the farm under study.

Key-words:

Logistics planning, efficient, economics results, agribusiness, farmers and consumer. 


\section{Sumário}

$1 \mathrm{O}$ tema e o problema de estudo............................................................................. 1

1.1. Introdução ao tema e ao problema de estudo 1

1.2. Objetivo do estudo 3

1.3. Objetivos intermediários do estudo 3

1.4. Delimitação e foco do estudo 3

1.5. Justificativa e relevância do estudo 4

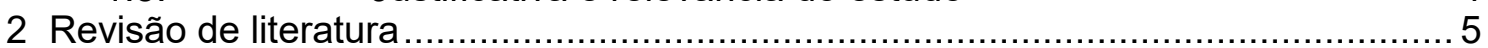

2.1. Logística e sua importância 5

2.2. Matriz Brasileira de Transporte e seu reflexo no Estado do Rio do

2.2.1. Modal Rodoviário .......................................................... 7

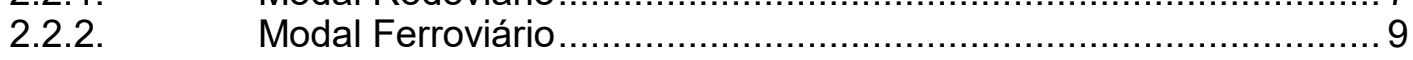

2.3. Distribuição Física de Produtos $\quad 12$

2.4. Armazenagem e Transporte 13

2.5. Cooperativas 15

2.5.1. $\quad$ Cooperativas de Distribuição .................................................... 16

2.6. Tecnologia da Informação 18

3 Métodos e procedimentos de coleta e de análise de dados do estudo ....................20

3.1. $\quad$ Tipo de pesquisa 21

3.2. Seleção dos entrevistados 21

3.3. Procedimentos e instrumentos de coleta de dados utilizados do

3.4. Formas de tratamento e análise dos dados coletados para 21

estudo 22

3.5. Limitações do método 22

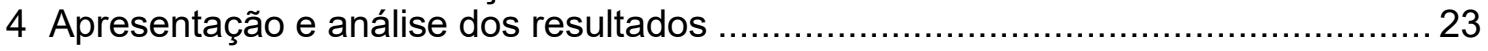

4.1. A Empresa $\quad 23$

4.2. Descrição e análise dos resultados 26

4.2.1. Armazenagem e Escoamento ................................................... 26

4.2.2. Transporte de produtos $\quad$....................................................... 27

4.2.3. Tecnologia de Informação e Equipamentos ................................ 28

4.2.4. Considerações ............................................................................ 29

5 Conclusões e recomendações para novos estudos .......................................... 31

5.1. Sugestões e recomendações para novos estudos 32

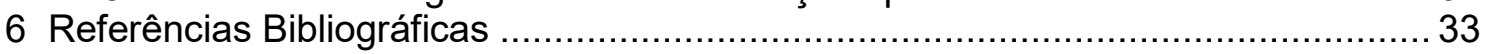

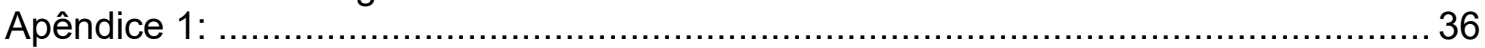

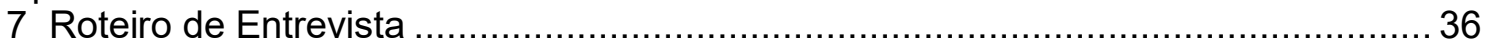




\section{Lista de figuras}

$\begin{array}{ll}\text { Figura 1. Malha Rodoviária no Estado do Rio de Janeiro } & 14\end{array}$

Figura 2. Malha Ferroviária no Estado do Rio de Janeiro 16

Figura 3. Caminhão entrando no armazém para descarga do produto. 21

Figura 4. Vista aérea da Fazenda $\quad 30$

Figura 5. Plantação de milho da Fazenda 31

Figura 6. Detalhe do Secador $\quad 31$

Figura 7. Galpão de produtos ensacados para seguir para a distribuição 31

Figura 8. Silo 32

\section{Lista de tabelas}

Tabela 1. Raio X das Rodovias Brasileiras em 2015

Tabela 2. Condições das Estradas Brasileiras em 2015

Tabela 3. Movimento Anual de Cargas Transportadas por Ferrovia 15

Tabela 4. Investimentos Privados - Concessões 15 


\section{0 tema e o problema de estudo}

Esse capítulo volta-se à apresentação do tema que se pretende desenvolver e do problema de estudo.

Assim, apresenta-se o problema que suscitou a proposta de investigação e respectivos objetivos de pesquisa. Na seqüência, são indicadas as suposições e as hipóteses do estudo e se informa a relevância e justificativa, bem como a delimitação e foco do estudo.

\subsection{Introdução ao tema e ao problema de estudo}

Cada vez mais as empresas/indústrias dão importância para a logística. Um tema de grande relevância para as organizações. O Brasil está em $66^{\circ}$ lugar no mundo em relação à qualidade de infra-estrutura e competência logística, atrás, inclusive, de países emergentes - SEBRAE (2014).

Alguns dos fatos que explicam esta posição do país neste ranking é que apenas $10 \%$ de 1,7 milhões de quilômetros de estradas são pavimentadas; dos 29.000 quilômetros de ferrovias, só $25 \%$ do que é produzido na agricultura é levado até os portos pela ferrovia - DNIT (2014).

Esses dados mostram que o Brasil ainda é muito precário em termos de modais de transporte e, como consequência: encarece o produto final, há perdas durante o transporte ocasionado pelo atrito dos grãos um com o outro devido o balanço do transporte pelas más condições das rodovias, e leva mais tempo do que o normal para a entrega de alimentos do que se tivesse infra-estrutura adequada. O fato é que o produtor deve escolher o modal de transporte mais adequado ao seu tipo de negócio, levando em consideração tempo, confiabilidade e preço de cada um.

A logística sempre foi uma área de extrema importância para um negócio, pois um bom planejamento da mesma influencia no custo final da mercadoria, barateando-a e fazendo com que tenha também mais demanda pelos produtos/serviços. Por isso, a logística é vista com relevância pelos produtores rurais. O grão/alimento deve sempre ser conservado e armazenado de forma correta nos silos para evitar assim danos e perdas: este é outro fator essencial para o negócio. Além disso, o produtor deve se preocupar também com a compra dos insumos para a produção, o que leva em conta adubos, sementes, máquinas, tecnologia etc. Isto deve ser bem arquitetado e planejado para não 
influenciar negativamente no custo final do produto e, consequentemente, inibe a demanda.

O ciclo da produção agrícola deve ser bem planejado para que não tenha gargalos na cadeia produtiva. É importante que os fornecedores comprem insumos de boa qualidade, já que um bom produto agrícola começa com insumos de boa qualidade também. A partir disso, os agricultores devem cultivar os grãos e cuidar de toda a parte de produção agrícola para que nasçam e cresçam com qualidade. A colheita deve ser feita na época certa e com os equipamentos adequados, depois devem ser armazenados também em silos para que os grãos sejam conservados.

Os grãos podem ser transportados aos centros processadores, aos comerciantes, atacadistas ou até mesmo diretamente para o consumidor: quanto menos intermediários houver mais barato o produto fica para o consumidor final. Toda esta logística agrícola tem que ser bem planejada e integrada entre todos estes pontos da cadeia para que se tenham melhores resultados para todas as partes envolvidas neste processo.

As estradas mal conservadas, ferrovias abandonadas, baixa qualidade do acesso terrestre aos portos, sem infra-estrutura de rios para navegação, falta de multimodalidade etc, tudo isso são problemas reais brasileiros e no Rio de Janeiro também. Infelizmente, o produtor rural tem que saber lidar também com estas questões extra-produção, além dos próprios problemas de produção agrícola. O cenário realmente não é muito favorável para os produtores.

A ferrovia seria o melhor modal para transportar os produtos agrícolas e, particularmente, para o próprio transporte dos grãos, já que pode levar a mercadoria em grande escala e, portanto, ao menor custo: porém este modal voltado para o ramo agrícola é praticamente inexistente no estado do Rio de Janeiro. Quanto ao transporte fluvial, são poucos os rios do estado que podem ser navegados e, além disso, muitos dependem das condições climáticas, que podem inviabilizar este modal nos períodos de estiagem. O modal mais comum utilizado hoje é o rodoviário, o qual também apresenta os seus problemas como estradas esburacadas e não pavimentadas. A falta de suporte do Governo é enorme, o que deveria ser tratado como uma das prioridades, na verdade, é esquecido e só agrava ainda mais o problema agrícola brasileiro. Apesar disso tudo, os produtores agrícolas buscam sempre minimizar estes problemas como podem, para levar um alimento de qualidade e com preço justo ao consumidor final. 
Portanto, há muito ainda que pesquisar e desenvolver neste quesito tão essencial para colaborar com o futuro do agronegócio brasileiro e melhorar as condições logísticas deste ramo.

Assim, este trabalho procura responder à seguinte pergunta: "Como o produtor agrícola de médio porte se estrutura para fazer a distribuição física de seus produtos no estado do Rio de Janeiro, visando atender o mercado consumidor da cidade do Rio de Janeiro?"

\subsection{Objetivo do estudo}

Identificar os principais elementos que impactam na gestão de atividades logísticas ligadas ao agronegócio para obter melhores resultados econômicos, tanto para o produtor quanto para o consumidor final.

\subsection{Objetivos intermediários do estudo}

- Analisar o impacto da multimodalidade nos preços finais dos produtos;

- Identificar as formas mais eficientes de armazenagem e transporte para obter melhores resultados;

- Realizar um levantamento dos principais problemas enfrentados pelos produtores rurais em termos de logística.

\subsection{Delimitação e foco do estudo}

O estudo, sob o aspecto conceitual, limita-se à análise dos fatores ligados à distribuição dos produtos agrícolas, não abordando os problemas ligados ao suprimento de insumos agrícolas nem da tecnologia de produção. Ficam excluídos os aspectos ligados à previsão e controle de estoque desses produtos e desenvolvido dentro do conceito de como se executar melhor a sua distribuição.

Apesar de ser um tema, aparentemente comum a produtores agrícolas de todo o Brasil, como se limitou o estudo ao entorno de um raio de 200 quilômetros da Região Metropolitana do Rio de Janeiro para análise dos empreendimentos agrícolas, portanto com peculiaridades inerentes próprias a essa região, seus resultados não podem ser generalizados a outras regiões brasileiras. Este estudo foi realizado no segundo semestre de 2016. 


\subsection{Justificativa e relevância do estudo}

Este estudo procura contribuir para a redução do custo do alimento no estado do Rio de Janeiro analisando o planejamento logístico mais adequado para a distribuição física dos produtos agrícolas, visando melhorar o resultado econômico dos produtores rurais e, consequentemente, conseguir um preço menor na comercialização dos produtos agrícolas.

Em face de similaridades análogas em termos de ação, este estudo pode também ser utilizado na implantação de unidade de produção de bens materiais, pois envolvem situações análogas com a do agronegócio, uma vez que ambos necessitam de aquisição de insumos, mão de obra e seu processo de suprimento de matérias-primas, bem como a sua distribuição para o mercado consumidor, a um preço justo.

Por fim, este estudo poderá ser também utilizado para elaboração de pesquisas posteriores que venham a enriquecer a bibliografia pouco existente sobre o assunto e, desta maneira, contribuir para o esclarecimento melhor dos problemas vivenciados pelos empresários do agronegócio. 


\section{Revisão de literatura}

\subsection{Logística e sua importância}

"Logística é a parte do Gerenciamento da Cadeia de Abastecimento que planeja, implementa e controla o fluxo e armazenamento eficiente e econômico de matérias-primas, materiais semi-acabados e produtos acabados, bem como as informações a eles relativas, desde o ponto de origem até o ponto de consumo, com o propósito de atender às exigências dos clientes" (Carvalho, 2002, p. 31).

Em outras palavras, a logística é a parte da organização que gerencia o fluxo do produto/matéria-prima desde a fabricação até o consumidor final. A logística tem como objetivo controlar com eficiência todo este processo da cadeia produtiva passando por inúmeras etapas até o consumidor final.

No ponto de vista do cliente, a logística tem como objetivo atender a necessidade do mesmo, entregando o produto/serviço desejado dentro do prazo combinado, atendendo assim a expectativa esperada com um custo razoável, conforme BALLOU, Ronald H (1993).

Através de uma gestão com eficiência, com uso de tecnologias, infraestrutura/equipamentos e mão de obra qualificada, obtêm-se excelentes resultados econômicos, segundo a Revista "Valor Setorial - Logística" (Março, 2016). Realizando um bom planejamento da logística, por consequência, há influência no custo final do produto, barateando-o e não transferindo assim a responsabilidade do custo de transporte para o cliente: afinal, ninguém quer pagar mais caro. Sendo assim, adequar a logística visando a redução de custos e manter a competitividade das empresas/produtores torna-se um grande desafio para o Brasil, segundo a Revista "Valor Setorial - Logística" (Março, 2016).

A competitividade tornou-se um paradigma para a economia mundial e a logística está totalmente interligada a ela, pois possui inúmeros elementos que podem ser harmonizados e otimizados para aumentar a eficiência de um processo logístico e majorando, consequentemente, a competitividade.

Alguns exemplos destes fatores são: a tecnologia de informação, a armazenagem, os modais de transporte, equipamentos, entre outros. Porém, mesmo que os produtores tenham feito um grande investimento nos fatores citados para obterem maiores resultados econômicos, é imprescindível que o governo também faça a sua parte, mas isso não ocorre no Brasil, conforme se tem verificado em vários fóruns reunindo representantes do governo e os 
empresários, como tem mostrado aqueles promovidos pela Folha de São Paulo, em São Paulo, reunindo especialistas no ramo, como ocorreu recentemente, no dia 25 de Outubro de 2016, ou ainda, como se viu no número especial da revista Exame sobre Infraestrutura: Anuário Exame 2016-2017: 20 anos para tirar o atraso, colocando a pergunta no que tange à infraestrutura: "Seremos um país decente?".

\subsection{Matriz Brasileira de Transporte e seu reflexo no Estado do Rio de Janeiro}

A Matriz brasileira de transporte é composta por cinco modais (rodoviário, ferroviário, aquaviário, dutoviário e aéreo). A importância relativa de cada tipo pode ser medida pela distância coberta pelo sistema, pelo volume de tráfego, pela receita e pela natureza da composição do tráfego, conforme Bowersox e Closs (2007). Porém, os modais que são mais utilizados hoje pelo agronegócio no Brasil são: rodoviário, ferroviário e hidroviário.

O ideal para todas as empresas que utilizam no mínimo dois modais de transportes para a distribuição de seus produtos é a multimodalidade, o que diminui tempo de entrega.

As cargas brasileiras são movimentadas através de rodovias, quando deveriam ser utilizadas com mais intensidade também através de ferrovias e hidrovias. Isso em tese, pois a realidade histórica do país não favorece a integração de modais. - É o que afirma o professor Paulo Resende, coordenador do Núcleo de Logística, Supply Chain e Infraestrutura da Fundação Dom Cabral em reportagem para a Revista "Valor Setorial - Logística" (Março, 2016). Segundo ele, o Brasil vive, desde a colonização, uma "cultura de substituição", criada a partir dos ciclos de exploração de produtos brasileiros. Ou seja, ouro sendo substituído por cana-de-açúcar, depois por café, e assim sucessivamente. O País não consegue criar uma cultura de planejamento de longo prazo, e isto levou a outro ponto crítico, que é a questão da conexão com o modal de transporte mais apropriado para o ciclo vigente.

Desta forma, o Brasil não avança na multimodalidade, entre outras razões, porque os projetos deveriam ser concebidos já multimodais. - Afirma Cesar Meireles, Diretor-Executivo da Associação Brasileira de Operadores Logísticos (Abol), em reportagem para a Revista "Valor Setorial - Logística" (Março, 2016). 
Apesar da realidade histórica do País não favorecer a integração de modais, ela garante expressivos ganhos para as empresas, como aumento de produtividade e eficiência.

Segundo a Revista "Valor Setorial - Logística", calcula-se que cerca de $60 \%$ do tempo de transporte de cargas é dedicado às etapas de carregamento e descarregamento. Este tempo elevado nas pontas, seja em terminais ou em portos, tem reflexo na ferrovia com a formação de filas de caminhões. Quando se integra os ativos, é possível reduzir este tipo de ineficiência do sistema logístico.

Apesar de todos os benefícios da multimodalidade para as empresas, o Governo não apóia esta função no país, inclusive há pagamento de dois seguros, duas vezes o Imposto sobre Circulação de Mercadorias e Serviços (ICMS) do frete quando se utiliza: rodo/aéreo, rodo/fluvial ou rodo/cabotagem.

Dentro deste tema de logística, o Brasil está ainda longe do ideal, consequentemente regride na matriz de transporte por causa de sua "cultura de substituição", burocracias e legislações.

\subsubsection{Modal Rodoviário}

No Brasil, aproximadamente $70 \%$ das mercadorias e $90 \%$ dos passageiros são transportados pelas rodovias. Porém, este modal acumula defasagem histórica que continua impondo limitações à competitividade do país. Da malha total de 1,72 milhão de quilômetros, apenas $12,4 \%$ são rodovias pavimentadas ou 213.000 quilômetros, sendo que mesmo nas estradas asfaltadas, onde o tráfego de veículos é mais intenso, prevalece a má qualidade das vias, conforme mostram as tabelas 1 e 2 (Dados e informações retirados da CNT divulgada na Revista "Valor Setorial - Logística" (Março, 2016).

Tabela 1. Raio X das Rodovias Brasileiras em 2015

\begin{tabular}{|l|l|}
\cline { 1 - 2 } Raio-X das rodovias (Brasil, 2015 - em km) & \multicolumn{1}{l}{} \\
\cline { 1 - 2 } Pavimentadas & 213.298 \\
\hline Não Pavimentadas & 1.353 .184 \\
\hline Planejadas & 154.192 \\
\hline Federais & 66.712 \\
\hline Estaduais & 119.691 \\
\hline Municipais & 26.826 \\
\hline Federais Duplicadas & 5.830 \\
\hline Federais em Duplicação & 1.587 \\
\hline Federais em Pistas Simples & 52.295 \\
\hline Fonte: Confederação Nacional do Transporte (CNT)
\end{tabular}

Tabela 2. Condições das Estradas Brasileiras em 2015 


\begin{tabular}{|l|l|}
\hline Condições das estradas (Brasil - 2015) & \multicolumn{1}{|l}{} \\
\hline Ótimo & $12,5 \%$ \\
\hline Bom & $30,2 \%$ \\
\hline Regular & $34,9 \%$ \\
\hline Ruim & $16,1 \%$ \\
\hline Péssimo & $6,3 \%$ \\
\hline
\end{tabular}

Fonte: Confederação Nacional do Transporte (CNT)

Segundo a própria CNT em reportagem para a Revista "Valor Setorial Logística" (Março, 2016), há 80,3\% de rodovias sob gestão pública e 19,7\% de vias sob concessão da iniciativa privada. Nos trechos concedidos os resultados foram melhores: $78,3 \%$ da extensão foi classificada como ótima ou boa e $21,7 \%$ como regular, ruim ou péssima. Já o estado geral das rodovias públicas é bastante crítico. Neste caso, $65,9 \%$ das vias foram consideradas regulares, ruins ou péssimas e somente $34,1 \%$ ótimas ou boas.

A precariedade das rodovias brasileiras impacta negativamente o caixa das empresas. Segundo estudo da Fundação Dom Cabral (FDC) publicado na Revista "Valor Setorial - Logística" (Março, 2016), caminhões que rodam em estradas com situação precária, sem pavimento, pista simples e sem sinalização adequada - que é o caso da maioria das rodovias públicas - registram acréscimo de $32 \%$ nos custos relativos a pneus, combustíveis e peças de manutenção, sem considerar o cálculo da vida útil do veículo. Já os caminhões que trafegam por rodovias com pedágios têm aumento médio nos custos de $18 \%$.

"Como o governo federal não consegue realizar os investimentos necessários, a diferença de qualidade entre as rodovias concedidas, onde há cobrança de pedágio, e as mantidas pelo poder público tende a se ampliar", afirma Bruno Batista, Diretor-Executivo da CNT em reportagem para a Revista "Valor Setorial - Logística" (Março, 2016, na página 79).

Devido à crise econômico-política que o Brasil atravessa, o poder público quebrou, inibindo assim os investidores. Mesmo existindo trechos rodoviários que podem ser atraentes para eles, o risco regulatório e a baixa credibilidade do governo dificultam.

Entretanto, as concessões são viáveis apenas em locais com grande movimentação de veículos, capazes de gerar receita nos pedágios, caso contrário, a administração pública seria o ideal.

Este é o contexto encontrado pelos produtores rurais no estado do Rio de Janeiro, há um grande tráfego diário de veículos, onde a maioria das rodovias é concedida, o que resulta no encarecimento do frete devido aos pedágios. Por 
outro lado, as rodovias são mais preservadas e bem cuidadas, diminuindo os riscos de perda/dano do produto, acidente com o veículo ou problemas de manutenção do mesmo.

Este modal é o mais utilizado pelos produtores rurais do estado, já que a ferrovia é quase inexistente. O transporte através de caminhões é mais flexível e também mais rápido que devido a curta distância entre as fazendas e os centros urbanos. $O$ fato é que o produtor deve escolher o modal de transporte mais adequado ao seu tipo de negócio, levando em consideração tempo, confiabilidade e preço de cada um. A Figuras 1 ilustra bem como estão distribuídos os ramais rodoviários pelo Estado.

Figura 1. Malha Rodoviária no Estado do Rio de Janeiro

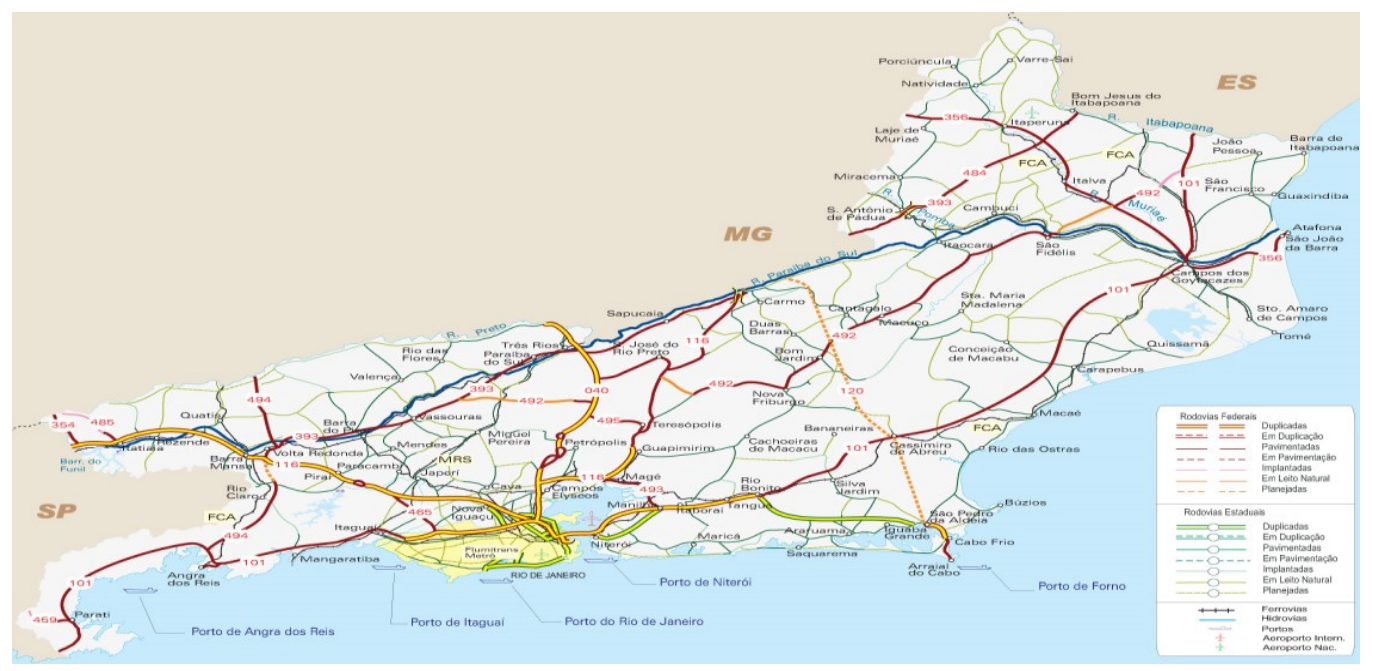

Fonte: www.rio-turismo.com.br

2.2.2. Modal Ferroviário

Segundo relatórios da Agência Nacional de Transportes Terrestres ANTT divulgados na Revista "Valor Setorial - Logística" (Março, 2016), o Brasil conta com cerca de 30.000 quilômetros em concessões de ferrovias com o setor privado. No entanto, apenas de 12 mil a 15 mil quilômetros estão em operação. O resto da malha está subutilizado ou ocioso.

A malha ferroviária brasileira necessita de investimentos para a expansão da capacidade, melhorias, produtividade e eficiência. Com isso, haverá redução de até $25 \%$ no preço do frete, segundo Luis Henrique Teixeira Baldez, presidente da Associação Nacional dos Usuários de Carga - ANUT em reportagem para a Revista "Valor Setorial - Logística" (Março, 2016). Segundo dados da própria ANUT, em 2015 foram transportados 475 milhões de toneladas de produtos e a perspectiva para este ano é de um crescimento entre $4 \%$ e $5 \%$, por conta de 
alguns investimentos em melhorias, como por exemplo, a velocidade da locomotiva. A velocidade média no Brasil é baixa em relação a outros países, oscilando entre 20 e 45 quilômetros por hora, quando deveria ser de 40 quilômetros por hora. Com o aumento de velocidade média, permite a empresa transportar um volume maior de mercadorias, segundo Baldez.

De acordo com último Balanço do Transporte Ferroviário de Cargas 2014, divulgado pela Associação Nacional dos Transportadores Ferroviários (ANTF) para a reportagem Revista "Valor Setorial - Logística” (Março, 2016), aponta que os investimentos por parte das concessionárias ferroviárias somam $R \$ 46,9$ bilhões de 1997 a 2014. Isto é bem ilustrado nas tabelas 3 e 4 .

Tabela 3. Movimento Anual de Cargas Transportadas por Ferrovia

\begin{tabular}{|l|l|}
\hline Ano & Movimento de Cargas $\times 10^{6} \mathrm{t}$ \\
\hline 2002 & 315,8 \\
\hline 2007 & 445,2 \\
\hline 2010 & 469,7 \\
\hline 2011 & 452,9 \\
\hline 2013 & 452 \\
\hline 2014 & 463,9 \\
\hline 2015 & 475 \\
\hline \multicolumn{2}{|l|}{ Fonte: Ministério dos Transportes, Dnit e ANTF }
\end{tabular}

Tabela 4. Investimentos Privados - Concessões

\begin{tabular}{|l|l|}
\hline Ano & Investimentos Privados $\left(\mathrm{R} \$ \times 10^{6}\right)$ \\
\hline 2002 & 724 \\
\hline 2007 & 2.737 \\
\hline 2010 & 3.037 \\
\hline 2011 & 4.739 \\
\hline 2012 & 4.988 \\
\hline 2013 & 4.792 \\
\hline 2014 & 5.938 \\
\hline 2015 & 5.900 \\
\hline \multicolumn{2}{|l|}{ Fonte: Ministério dos Transportes, Dnit e ANTF }
\end{tabular}

As tabelas ilustram que, mesmo com o momento econômico turbulento que o Brasil passa hoje, a indústria ferroviária continuará em alta. Esse cenário não se aplica muito bem ao Estado do Rio de Janeiro, pois devido a sua característica pioneira de possuir a primeira estrada de ferro do Brasil (Leopoldina), as ferrovias utilizam bitolas estreitas na parte Norte do Estado (o que impossibilita o transporte eficiente de cargas nessa região) com ramais que ligam até a cidade de Vitória (ES), aonde se encontra um importante porto. $\mathrm{Na}$ parte sul do Estado, as ferrovias possuem bitolas normais, porém estão em fase 
de revitalização com as companhias concessionárias, as quais se dedicam a transportes, quase exclusivamente, de minérios de ferro e produtos siderúrgicos.

Como o Estado do Rio de Janeiro não é produtor e exportador em larga escala de produtos agropecuários, o mesmo carece de portos e ferrovias especializados para estes fins. Por eliminação, os produtores rurais do estado têm como única opção usar o modal rodoviário, até porque é mais perto do centro urbano, mais rápido e muito mais flexível que o ferroviário.

O produtor rural deveria ter flexibilidade em escolher qual modal de transporte lhe é favorável em termos de custo de transporte para o escoamento de seu produto. Isso em tese, pois no Estado do Rio de Janeiro as ferrovias são obsoletas e inadequadas, e a cabotagem torna-se inviável devido às péssimas condições dos portos do Estado. Portanto, por eliminação, a rodovia torna-se o melhor modal para ser utilizado na distribuição. E o governo, por sua vez, incentiva este modal, já que o lobby da indústria automobilística é gigante.

A Figura 2 ilustra bem como estão distribuídos os ramais ferroviários pelo Estado.

Figura 2. Malha Ferroviária no Estado do Rio de Janeiro

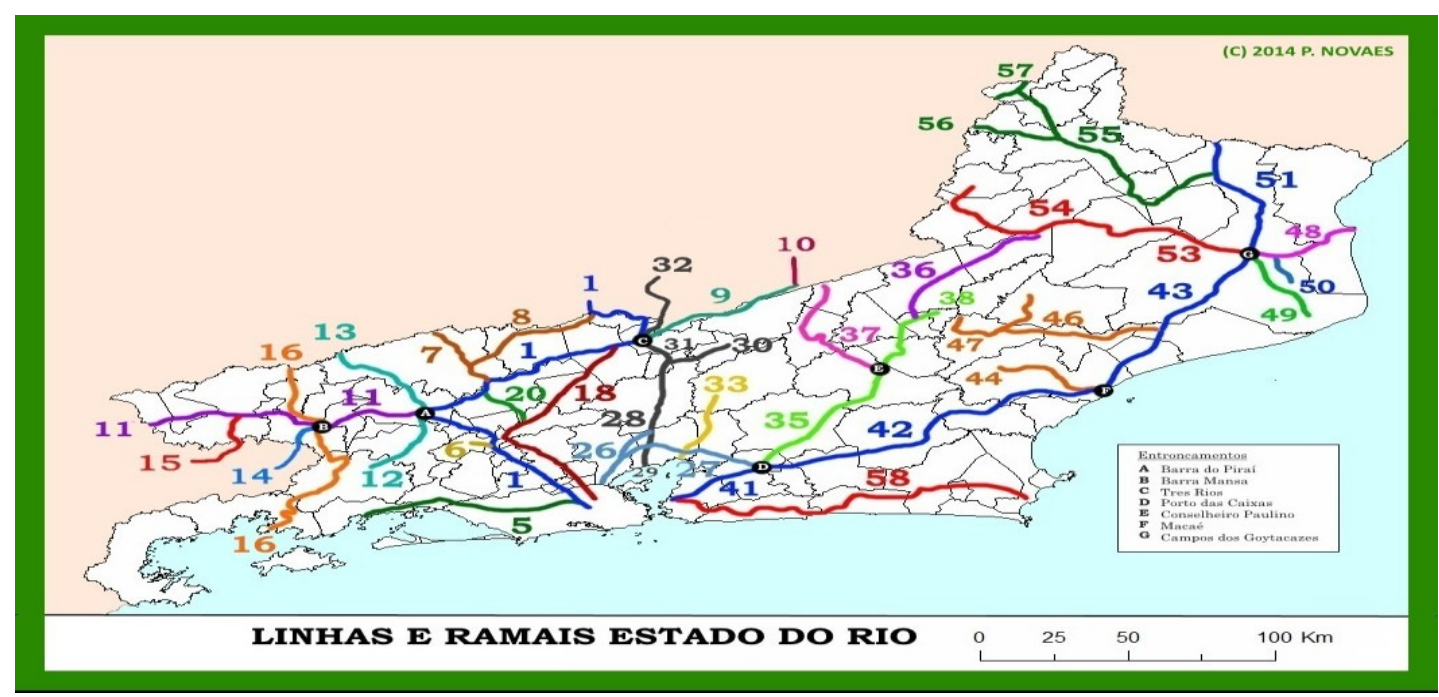

Fonte: www.agenciaspostais.com.br 


\subsection{Distribuição Física de Produtos}

Conforme BALLOU (1993), pode-se entender como suprimento de materiais a fase do fluxo de insumos necessários para a produção envolvendo seus fornecedores, e a de distribuição física como a fase de distribuição dos produtos até o seu destino final, envolvendo armazenamento e transporte.

Em outras palavras, a distribuição física de produtos trata da movimentação, estocagem e processamento dos pedidos de produtos acabados (ou semi) da empresa/fábrica ao mercado e absorve cerca de 2/3 dos custos logísticos.

Por este motivo, as empresas focam no processo de distribuição como "ultima fronteira" para diminuição de custos, uma vez que os mesmos são muito elevados dentro deste processo, principalmente no Brasil. O foco em escoar o produto de uma forma mais rápida por um custo baixo também deve ser levado em conta para aumentar a lucratividade da produção.

Um dos vários motivos para o alto custo no processo é devido à distribuição de materiais, no Brasil, basicamente ser realizada através de apenas um modal (Rodoviário), este que por sua vez é mais rápido e flexível.

Este modal é muito utilizado no transporte de matéria-prima, envolvido no processo de colheita até os silos/armazéns, seguido da expedição, utilizado também no transporte de insumos e adubos, e no transporte de produtos semiacabados, como no caso do gado que é levado do campo até o frigorífico para ser abatido e suas peças separadas para serem distribuídas também através das rodovias, onde a maioria destina-se a centros de distribuição - CD.

Os centros de distribuição são fundamentais no sistema de logística de uma empresa, situados geralmente em rodovias ou próxima a elas, em locais de fácil acesso a grandes caminhões e carretas, além de funcionarem como peças estratégicas para o abastecimento de lojas ou entregas de produtos aos consumidores finais. Eles se multiplicam pelo País, seguindo a rota de expansão das empresas e a necessidade de estar cada vez mais perto do cliente, encurtando distâncias e reduzindo os custos de transporte das mercadorias até o destino final (CASTRO, 2006).

Para especialistas - em reportagem à Revista "Valor Setorial - Logística" (Março, 2016) - a construção de CD próprio torna-se viável quando a operação exige espaços superiores a dez mil metros quadrados, facilitando o ganho em escala, quando a empresa tem experiência em operar o equipamento e o empresário está disposto a fazer um investimento de longo prazo. Por isso, é 
preciso avaliar cuidadosamente as características da operação e da própria empresa antes de decidir.

\subsection{Armazenagem e Transporte}

Conforme BALLOU, Ronald H (1993), a armazenagem e manuseio de mercadorias é parte do Sistema de Logística de uma empresa que abriga Produtos (matéria-prima, produtos acabados e semi-acabados) em certos nós de sua cadeia de suprimento e informa situação, condição e disposição dos itens armazenados.

A armazenagem é um dos pontos cruciais dentro da logística de qualquer ramo de negócio, principalmente no agronegócio, onde se precisa fazer uma gestão eficiente dos diversos produtos, guardando-os em locais adequados de conservação, permanecendo por um mínimo período possível e, assim, seguir com o transporte dos mesmos para os seus respectivos destinos.

Isto tudo, inclusive durante o transporte, deve ser feito através de um processo integrado e com total controle.

Tomando como exemplo grãos (milho, soja, café, etc), após sua colheita, os produtos, após serem retirados do campo, eles seguem para os silos, dependendo do tipo de produto e a finalidade que se destina a unidade, ele pode seguir para o silo hermético, metálico ou elevado de concreto. Lá, o grão deve ser estocado em um ambiente arejado, limpo e com temperatura adequada dependendo também do tipo de produto, esperando certo período de tempo, levando em consideração a demanda, até que seja levado ao transporte para distribuição. A identificação, conferência, separação dos itens e o registro das operações são de grande importância principalmente durante este processo.

O processo de armazenagem é de fato muito difícil de ser gerido, exige muita tecnologia, equipamentos bem adequados, bom manuseio e muito cuidado para que não haja nenhuma perda. Esta perda se trata dos danos provocados pelo atrito dos grãos e o próprio manuseio, ao cuidado com as ações de insetos, pragas, animais ou fungos que causam a fermentação e prejudica o valor nutritivo dos grãos, e também em relação ao roubo/furto de mercadoria. Por isso é muito importante que sempre se faça inventário durante todo processo.

Quando o sistema de armazenagem é bem feito, ele proporciona diversos benefícios para os produtores, pois por meio do controle de estoque obtém-se redução dos custos e distribuição dos produtos no tempo correto. Fora isso, o uso da mão de obra, da energia e dos equipamentos, a rotatividade do estoque 
e controle de perdas também são itens fundamentais que devem ser analisados ao utilizar o armazém.

Porém, um dos pontos que talvez seja o mais fundamental para o corte de custos por parte dos produtores, seja a otimização do espaço do armazém, pois espaço ocioso traduz-se em perda econômica. O ideal para os produtores seria um armazém de acordo com o tamanho da própria produção ou então, no caso dos pequenos produtores rurais do estado do Rio de Janeiro, é mais válido e viável aproveitar de um compartilhamento de armazém entre os produtores rurais vizinhos. O uso desta prática - podendo ser alugada ou comprada - permite que o proprietário do armazém tenha um maior lucro devido à utilização máxima de capacidade do local e é uma economia de custos para os produtores que não tem como arcar com um armazém próprio ou por estarem em época de safra baixa (poucas vendas). Esta seria uma excelente alternativa por parte dos produtores rurais que buscam redução de custo nas operações logísticas e maior competitividade no mercado do ramo.

$\mathrm{Na}$ etapa de transporte, o produto deve manter o "nível" de armazenamento tão parecido quanto os dos silos para que não se tenham perdas durante o escoamento, como o atrito entre os grãos, por exemplo, causado pelo balanço dos caminhões ao se depararem com rodovias esburacadas.

Devido às legislações/restrições dos principais centros urbanos, como do Rio de Janeiro, por exemplo, as transportadoras tiveram que aumentar o número de caminhões em função da troca de modelos maiores por vários caminhões menores. O produto deve ser bem manuseado durante esta troca para que também não haja perdas/danos.

Por isso que se faz necessário o apoio do governo aos modais de transporte, pois o modal ideal do agronegócio seria a ferrovia, a qual tem um custo menor de transporte e pode transportar muito mais produtos que o veículo rodoviário, por exemplo. Como no Rio de Janeiro as ferrovias são precárias, o modal rodoviário é o mais utilizado para o transporte dos produtos agrícolas, sendo também o mais caro e menos seguro para seu transporte, como se pode notar, através do noticiário da mídia falada ou escrita, onde se ressalta o aumento do roubo de cargas, ultimamente de café no interior de São Paulo, pelo valor que este produto tem alcançado no mercado.

Este mesmo processo de transporte se aplica aos produtos mais perecíveis, como a carne, por exemplo. Porém, neste caso deve-se ter muito mais cuidado, pois no frigorífico as carnes devem ser colocadas em conserva e 
preservadas a temperaturas ideais até serem transportadas para os Centros de Distribuição ou portos, tudo isso feito com o máximo controle da temperatura do ambiente.

Desta forma, todos "saem ganhando", quando o foco é otimizar todos os recursos por gerar economias de escala. Portanto, o gerenciamento propício do armazém possibilita redução de custos dos produtores, e evita a perda e risco de envelhecimento do produto estocado.

Para o melhor gerenciamento dos processos de distribuição dos produtos, o investimento em Tecnologia de Informação é requisitado e primordial.

\subsection{Cooperativas}

Cooperativa é uma organização constituída por membros de determinado grupo econômico ou social que objetiva desempenhar, em benefício comum, determinada atividade. As premissas do cooperativismo são: Identidade de propósitos e interesses; Ação conjunta, voluntária e objetiva para coordenação de contribuição e serviços; e Obtenção de resultado útil e comum a todos. - (SEBRAE, 2016)

Por se tratar de uma organização, há certa burocracia e legislações a serem cumpridas para a implantação da mesma, como por exemplo: não é permitida a existência de parentesco até $2^{\circ}$ grau em linha reta ou colateral de quaisquer pessoas componentes dos órgãos de administração ou fiscalização da cooperativa; menores de 18 anos de idade só poderão fazer parte de sociedades cooperativas se assistidos por responsável legal; o Estatuto Social e a Ata de Constituição, antes de ser levados à Junta Comercial, deverão ser apreciados pela Organização das Cooperativas do Estado, a fim de verificar se não conflita com a legislação cooperativista vigente (Lei 5.764 de 16 de Dezembro de 1971). O associado de Cooperativa é contribuinte obrigatório da Previdência Social conforme Instrução Normativa n 84 de 17/12/2002 publicada no DOU- I de 23/12/2002, prescrita no Art. $2^{\circ}$, III, L. Após a Assembléia Geral de Constituição e análise da Organização das Cooperativas do Estado, torna-se necessário fazer o registro da Cooperativa na Junta Comercial do Estado, em seguida a aprovação dos documentos na Junta, deverão ser encaminhados à Receita Federal para retirada do CNPJ, segundo Organização das Cooperativas do Estado do Rio Grande do Sul (OCERGS) publicada no site do Canal Rural (atualizado em 2015). 
Antes de criar uma cooperativa é preciso saber: se há necessidade da criação da mesma e se seria a melhor solução, se a cooperativa seria viável econômica e socialmente, e determinar os objetivos. O processo de criação de uma cooperativa requer muitos documentos e passos a serem tomados, podendo levar muito tempo dependendo do tipo de cooperativa.

\subsubsection{Cooperativas de Distribuição}

Conforme estudo realizado pelo Instituto de Logística e Supply Chain ILOS, em 2015, envolvendo 121 grandes indústrias de vários segmentos, do total de recursos financeiros destinados às atividades logísticas, $61 \%$ representam gastos com prestadores de serviços e 39\% com custos externos, o que coincide, em termos práticos, com o que afirma Ballou, que os custos de Distribuição de produtos representam grande parte dos custos de qualquer empresa dedicada à produção de bens manufaturados e que envolvem atividades de custos conflitantes que deverão ser otimizados para que ela se torne competitiva.

Empresas de grande porte, que tem um mercado diversificado geograficamente, isto é, em regiões distantes procuram diminuir esses custos através da criação de Centro de Distribuição, nele concentrando atividades de manutenção de estoque, armazenamento, transporte e tecnologia de informação.

Por outro lado, quando se analisam as atividades do agronegócio, essas mesmas atividades são necessárias, com o diferencial de que exigem cuidados específicos da área, principalmente nos cuidados relativos à armazenagem e transporte por serem bens perecíveis: climatização no estoque e cuidados na embalagem para o seu manuseio e movimentação.

Os empresários ligados ao agronegócio têm, portanto, os mesmos problemas ligados aos da produção de bens manufaturados em termos de logística de distribuição.

A cooperativa de distribuição em termos de concepção poderia ser montada fazendo-se analogia às atividades desenvolvidas em um Centro de Distribuição de uma empresa, com o diferencial de ser um investimento compartilhado em forma de cooperativa - portanto, com uma reunião de empresários fazendeiros - pelo fato simples de que cada um, isoladamente, não poderia diminuir seus custos de distribuição por falta de recursos econômicofinanceiros (armazenamento e transporte exigem imobilização de capital grande) e também escala para que se consiga negociar frete e aluguel de silos de armazenagem. Como conseqüência, ele acaba executando essas atividades 
inadequadamente, resultando em preços elevados ao consumidor final e, em termos de exportação, pouco competitivo.

Figura 3. Caminhão entrando no armazém para descarga do produto.

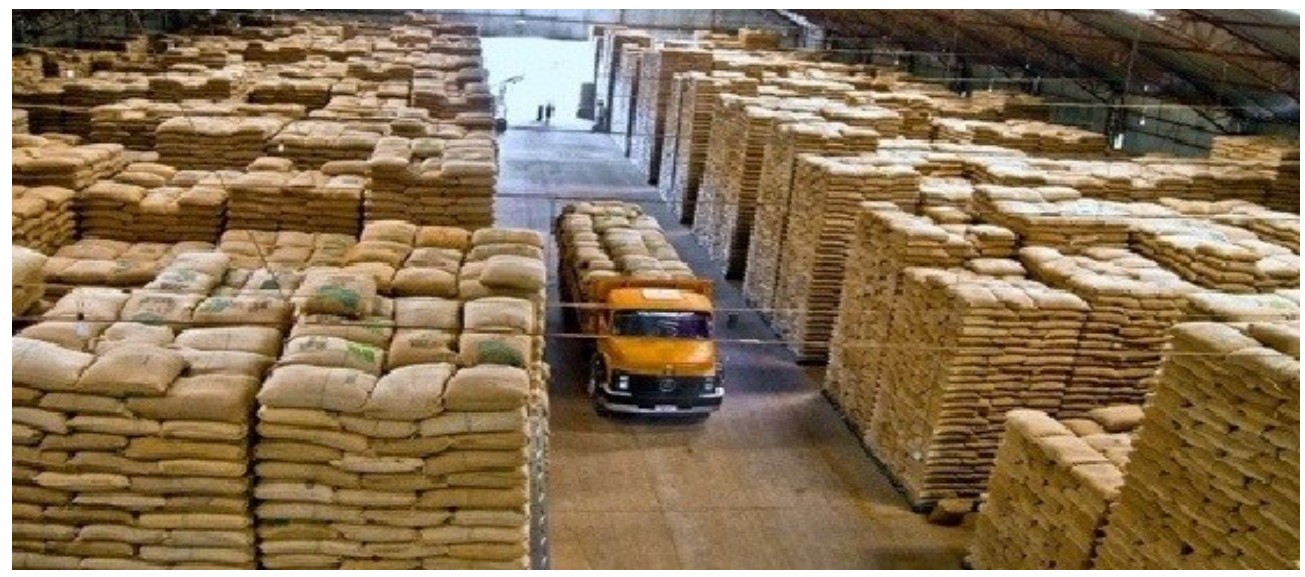

Fonte: www.ruralcentro.uol.com.br

A foto da figura 3 mostra como geralmente se armazenam grãos em grande escala, num processo de armazenagem horizontalizado para a rapidez do processo de carga e descarga com os caminhões entrando com a carga para o armazém, conforme recomendado por Ballou (1993), quando se armazenam produtos de grande giro de estoque, em grandes instalações de armazenamento. Esta condição pode ser encontrada em um grande armazém de uma cooperativa de distribuição física.

Assim, a cooperativa de distribuição torna-se uma alternativa interessante para os produtores rurais, principalmente para os menores produtores, já que os inserem como competitivos em meio à concorrência no mercado.

A prática das cooperativas tem a intenção de defender os produtores, visto que o investimento público em infra-estrutura é precário.

É importante, aqui, lembrar que na Logística a diminuição dos custos logísticos não depende apenas do empresariado privado, mas também da infraestrutura necessária para o desenvolvimento de suas atividades, onde entra a necessidade de investimento público nos vários modais de transporte e sua modernização que exigem pesados recursos e, em face do momento por que passa a economia brasileira, simplesmente precário. Conforme dados do IPEA em estudo de 2016, a taxa de crescimento dos investimentos públicos de 2011 a 2015 caiu 4\% em relação aos outros anos anteriores e, provavelmente, será ainda menor nos próximos anos. 
Tendo em vista este quadro, o uso de cooperativas de distribuição pode ser um instrumento importante para reduzir custos operacionais.

\subsection{Tecnologia da Informação}

Antes mesmo do uso da tecnologia com as máquinas e equipamentos, o trabalho com a "Informação" sempre foi o mais importante e algo muito valioso para a organização, pois se trata de um conjunto de dados com determinadas classificações que, quando organizados, podem ser utilizados para atingir os objetivos de uma determinada empresa. Estes dados se traduzem em informações privilegiadas de mercado e com isso as empresas podem tomar decisões baseadas nestas informações.

Pode-se perceber assim que, de fato, as informações são extremamente relevantes e é por isso que as organizações estão cada vez mais investindo em captar/obter e reter informações, assim elas se tornam mais competitivas. Porém, existem empresas que têm dificuldade em manter e obter informação ou, pior ainda, fazer o uso errado das mesmas e, como consequência, tomar decisões precipitadas.

Desta forma, a Tecnologia pode ser inserida dentre a análise de dados para transformá-los em informações relevantes e fáceis de serem decifradas, minimizando o risco de perda de informações e más tomadas de decisão.

A Tecnologia da Informação é o conjunto de informações que é utilizado em diversas áreas específicas, que usa a computação para obter, armazenar e utilizar as informações.

"Segundo a Associação Brasileira de Empresas de Softwares (Abes), o setor de TI (incluindo os segmentos de hardware, software e serviços) cresceu mais de $9 \%$, contra a média global de $5,6 \%$. A pesquisa aponta que o Brasil tem papel de destaque na América Latina. Em 2015, o país recebeu quase 60 bilhões de dólares de investimentos na área. Isso representa $45 \%$ do total investido na região" - (conforme mostra o site do "Guia do Estudante" atualizada em Outubro de 2016).

Ao analisarmos esta informação no contexto do agronegócio, o alto investimento em TI é mais visível no Centro-Oeste brasileiro, em fazendas imensas com produção em larga escala, porém quando se trata de produtores rurais do Estado do Rio de Janeiro, o investimento em TI é bem menor, devido ao baixo capital financeiro disponível e por serem proprietários de pequenas áreas de produção em sua maioria. Portanto, a TI é algo que se diferencia (e 
muito) dos concorrentes, pois nem todos a utilizam em suas operações logísticas.

Mas este investimento em Tecnologia da Informação também deve ser previamente medido para que não precise investir mais que o necessário e depois obter gastos desnecessários. Como por exemplo, um produtor rural que resolve investir pesado em Tecnologia da Informação, comprando máquinas e equipamentos de altíssima geração, computadores com processamento veloz com uma grande base de dados para uma safra que é colhida no máximo duas vezes por ano e há uma baixa rotatividade no estoque, este produtor está tendo gastos totalmente desnecessários com a TI que foi investida. Comprar máquinas de boa qualidade não significa adquirir as mais caras e sofisticadas, mas sim aquelas que possuem os recursos necessários para a produção. Sendo assim, quanto mais um produtor rural souber administrar os investimentos em $\mathrm{TI}$ necessários para sua produção, mais competitivo ele se torna em relação ao concorrente, o que também ocorre no Estado do Rio de Janeiro.

O uso de mais tecnologia cria uma vantagem competitiva em relação à concorrência, porque implica em operações mais automatizadas, com menos uso de mão de obra e sistemas mais modernos de controle e gestão de estoques. - (Conforme explica Marcos Bagnolesi, Diretor Comercial da ID Logistics Brasil em reportagem para a Revista "Valor Setorial - Logística”, Março de 2016).

Assim, a tecnologia se torna uma peça fundamental no processo de modernização da produção e substituição de certos materiais nas operações logísticas. Ela incluiu a substituição do papel, por exemplo, pois quando se faz a leitura do código de barras do produto, confirmando que o material embalado corresponde ao pedido do cliente, a informação fica on-line para ser gerenciada por todos os envolvidos no processo. No agronegócio também não é diferente, pois para ele ser competitivo necessita resolver o problema da pressão por eficiência nos armazéns e pelo rastreamento total dos itens transportados exige apoio de sistemas, sensores, máquinas modernas, etc.

O ideal é que todas as operações sejam integradas e haja troca de informação rápida entre as áreas, promovendo um modelo mais sustentável de produção e operação, conforme Revista "Valor Setorial - Logística" - Março de 2016).

Nos armazéns, a inteligência operacional demandará estratégias capazes de reduzir o estoque de produtos. Afinal, o capital não pode ficar imobilizado em forme de estoque por muito tempo. O uso intensivo de 
tecnologias permite a redução de estoques, com reposição automática dos produtos (dependendo da safra e da capacidade produtiva da fazenda analisada), o que reduz os custos. O uso dos sensores nos armazéns e durante o transporte dos produtos também é extremamente importante, pois eles conseguem capturar informações sobre rastreamento, temperatura, movimentação em armazéns, etc. Com estes sensores, a comunicação entre as máquinas migra para o conceito de internet, onde a conectividade entre equipamentos armazéns e sistema é total.

A idéia em si da TI é automatizar os processos e, conseqüentemente, otimizá-los. A automação de processos traz ganhos em eficiência e reduz custos de operação. Enquanto as máquinas monitoram os produtos, as pessoas ficam livres para analisar as informações e propor soluções de maior eficiência. Conforme Camilo Manfredi, Diretor de Operações da NeoGrid, em reportagem para a Revista "Valor Setorial - Logística" - Março de 2016).

No Brasil, a modernização dos sistemas logísticos anda a passos mais lentos do que nos países desenvolvidos, mas os operadores logísticos e profissionais de mercado sabem que investir em sistemas e Tecnologia da Informação é o caminho mais curto para trilhar quando se quer ser competitivo no mercado.

No Estado do Rio de Janeiro, caminha-se a passos mais lentos ainda quando comparado à região Centro-Oeste do Brasil, pois no Estado não há grandes produtores rurais devido à sua característica de minifúndios. Sendo assim, a Tecnologia de Informação só é empregada em setores específicos do agronegócio, como genética por exemplo. Nos demais setores qualquer investimento é válido para agregar valor, mas a maioria dos produtores rurais carece de recursos financeiros para aplicar em sua produção.

\section{Métodos e procedimentos de coleta e de análise de dados do estudo}

Este capítulo pretende informar sobre as diversas decisões acerca da forma como este estudo foi realizado. 


\subsection{Tipo de pesquisa}

O tipo de pesquisa adotado para este trabalho é o estudo de caso de natureza exploratória, realizado a partir de uma pesquisa bibliográfica em livros, revistas setoriais especializadas, sites e elaborado através de uma entrevista em profundidade por meio de um roteiro de entrevista semi-estruturado.

A investigação exploratória, que não deve ser confundida com leitura exploratória, é realizada em área na qual há pouco conhecimento acumulado e sistematizado. Por sua natureza de sondagem, não comporta hipóteses que, todavia, poderão surgir durante ou ao final da pesquisa (VERGARA, Sylvia Constant, 2005).

Este tipo de pesquisa tem como objetivo proporcionar maior familiaridade com o problema, com vistas a torná-lo mais explícito ou a construir hipóteses. A grande maioria dessas pesquisas envolve: (a) levantamento bibliográfico; (b) entrevistas com pessoas que tiveram experiências práticas com o problema pesquisado; e (c) análise de exemplos que estimulem a compreensão. As pesquisas exploratórias podem ser classificadas como: pesquisa bibliográfica e estudo de caso (GIL, 2007).

O estudo de caso foi o método escolhido para esta pesquisa, pois é o circunscrito a uma ou poucas unidades, entendidas essas como pessoa, família, produto, empresa, órgão público, comunidade ou mesmo país. Tem caráter de profundidade e detalhamento. Pode ou não ser realizada no campo (VERGARA, Sylvia Constant, 2005).

\subsection{Seleção dos entrevistados}

O critério de seleção adotado foi a de acessibilidade e, também, do conhecimento sobre o assunto, para o desenvolvimento desta pesquisa.

A entrevista foi realizada com o Sr. Sérvulo Marton, sócio-gerente da Fazenda Ilha da Saudade, localizada na BR 101, no KM 161, perto da cidade de Macaé a aproximadamente 190 quilômetros da cidade do Rio de Janeiro.

\subsection{Procedimentos e instrumentos de coleta de dados utilizados no estudo}

A entrevista de profundidade é definida como uma entrevista nãoestruturada, direta, pessoal, em que um respondente de cada vez é instado por um entrevistador altamente qualificado a revelar motivações, crenças, atitudes e sentimentos sobre determinado tópico (NOTESS, 1996). 
Além de ser uma pesquisa exploratória, ela também é de natureza qualitativa, fundamentada a partir de entrevista em profundidade. A abordagem qualitativa permite uma narrativa rica em detalhes (GERPHAT, 2004).

A entrevista foi desenvolvida com base em itens previamente selecionados na parte de revisão de literatura que serviram como roteiro para conduzir a entrevista. A mesma foi individual, in loco, e gravada com autorização do entrevistado e feita no escritório da própria Fazenda, a qual durou aproximadamente 2 horas e 30 minutos.

\subsection{Formas de tratamento e análise dos dados coletados para o estudo}

Os dados extraídos da entrevista foram tratados de forma qualitativa, sendo apresentados de forma estruturada para responder ao problema colocado no início desta pesquisa, ou seja, a obtenção de melhores resultados econômicos para a empresa.

\subsection{Limitações do método}

Uma das limitações da pesquisa exploratória qualitativa é que não há crédito quanto à sua generalização (KATES, 1998), ou seja, é preciso tomar cuidado com as generalizações desse tipo de pesquisa, pois esta é limitada ao grupo dos entrevistados. Outra limitação é dada por Creswell (2003), que diz que há a possibilidade de haver viés do pesquisador, isto é, como o pesquisador interpreta os dados, é provável que ele interprete de acordo com seu olhar pessoal, influenciando então a interpretação dos dados.

Portanto, os resultados deste estudo de caso abordado não devem ser generalizados e aplicados para todos os produtores rurais. As análises se aplicam a exclusivamente à Fazenda Ilha da Saudade. 


\section{Apresentação e análise dos resultados}

Este capítulo, organizado em duas seções, apresenta e discute os principais resultados alcançados, analisa e discute suas implicações e produz sugestões sobre o estudo previamente selecionado.

A primeira seção descreve a empresa de acordo com os resultados da pesquisa exploratória, realizada pela entrevista. A segunda seção analisa os resultados da pesquisa e propõe soluções.

\subsection{A Empresa}

A Fazenda Ilha da Saudade está localizada na BR 101 no KM 161, próxima à cidade de Macaé e existe há mais de 60 anos.

A Fazenda tem 350 Hectares de área, sendo 300 de área plantada e os outros 50 de pastagem, contendo um total de 120 cabeças de gado voltadas para corte e leite. Os produtos cultivados na Fazenda são arroz, feijão e milho, sendo estes dois últimos os principais.

O atual administrador, Sérvulo Marton, é um senhor de 50 anos, com um vasto conhecimento na área agrícola, pois começou a trabalhar no setor aos 14 anos na propriedade do pai no interior de São Paulo e hoje administra a llha da Saudade há 16 anos.

A Fazenda possui doze funcionários, sendo três na parte operacional, oito na lavoura e o gestor. Porém, todos os funcionários sabem fazer "um pouco de tudo", já que para trabalhar no campo há necessidade deste requisito, portanto, os funcionários aprendem a realizar diversas funções sob a orientação do gestor. Os funcionários têm diversos cursos de novos conhecimentos e treinamento, tais como: construção de cercas, operação de máquinas, de aplicação de agrotóxicos e de segurança do trabalho, promovidos pelo SENAR e pelo Sindicato de trabalhadores rurais de Macaé.

Em 2015, a Fazenda inaugurou o novo Silo com 838 metros cúbicos, com o objetivo de armazenar um maior volume de grãos de forma mais segura. Ela possui também diversos equipamentos agrícolas multifuncionais, todos usados e próprios, porém muito bem cuidados, evidenciando uma boa manutenção preventiva, o que é essencial no processo produtivo. 
Devido à sua localização privilegiada (na beira do rio e da rodovia), a Fazenda não necessita de transporte próprio para a entrega dos seus produtos. Os próprios clientes buscam a mercadoria na Fazenda e, com isso, ela não tem nenhum custo com transporte dos produtos. A Fazenda possui caminhão apenas voltado para serviços de manutenção, compra de insumos e transporte requerido nos processos operacionais da Fazenda.

Seus principais fornecedores são: Casa do Adubo, Central Rio Agropecuária, Apoio Agrícola e Comercial Friburguense. Os principais clientes são: Casa Almeida e Bastos e São Geraldo Lajenses.

A foto da figura 4 mostra a vista aérea da localização da Fazenda.

Figura 4. Vista aérea da Fazenda

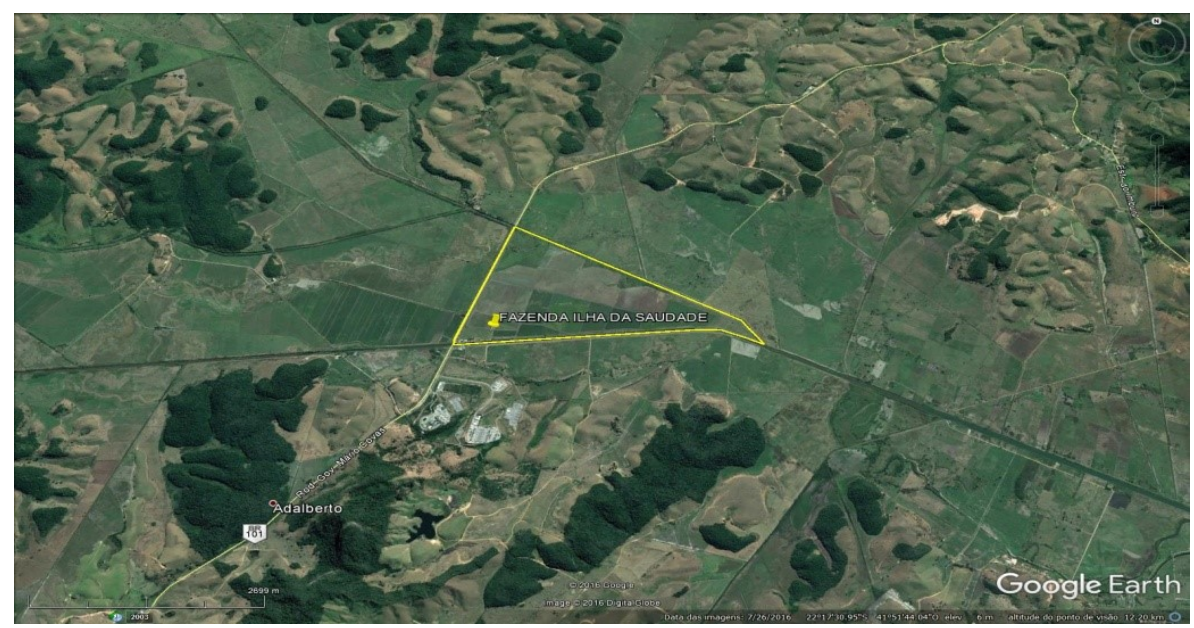

Fonte: Google Earth

As fotos das figuras 5, 6, 7 e 8, tiradas pelo autor, procuram ilustrar fotograficamente a sequência dos processos operacionais desenvolvidos na produção da Fazenda, desde o seu plantio, com uma visão panorâmica da paisagem da plantação de milho da Fazenda; o processo de secagem no secador após a colheita; como ficam armazenados em sacas os produtos secos; e o silo de armazenamento para estratégia de distribuição de produtos de menor demanda ou para estratégia da comercialização dos produtos da Fazenda. 
Figura 5. Plantação de milho da Fazenda

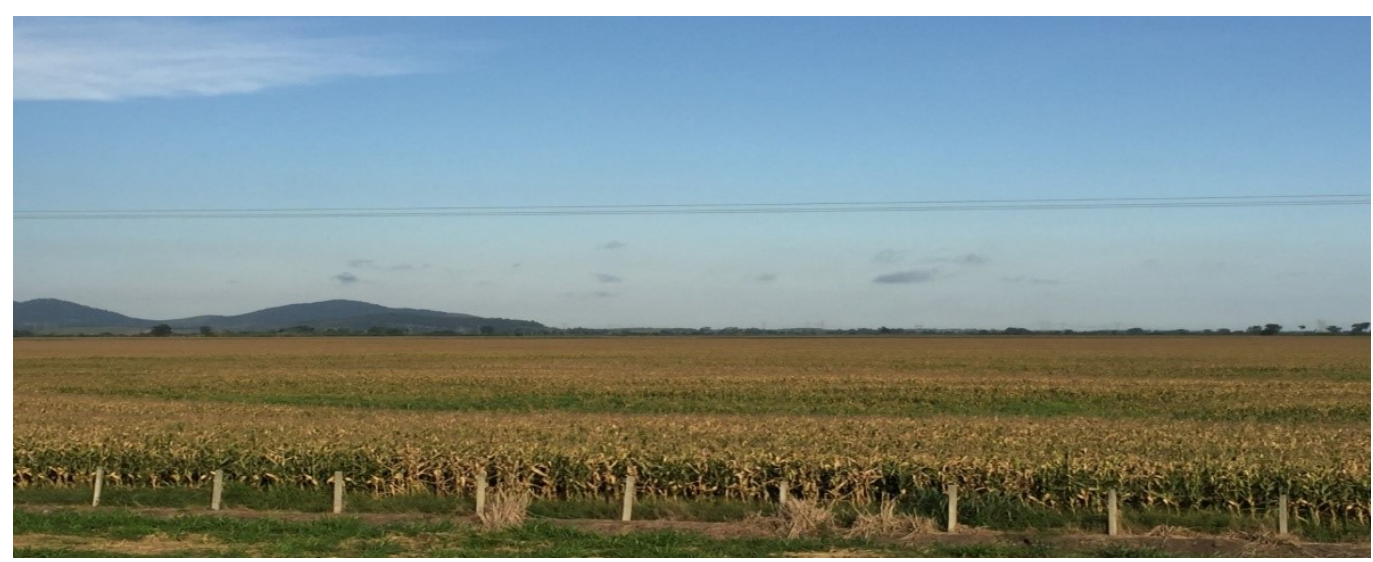

Fonte: Foto tirada pelo autor

Figura 6. Detalhe do Secador

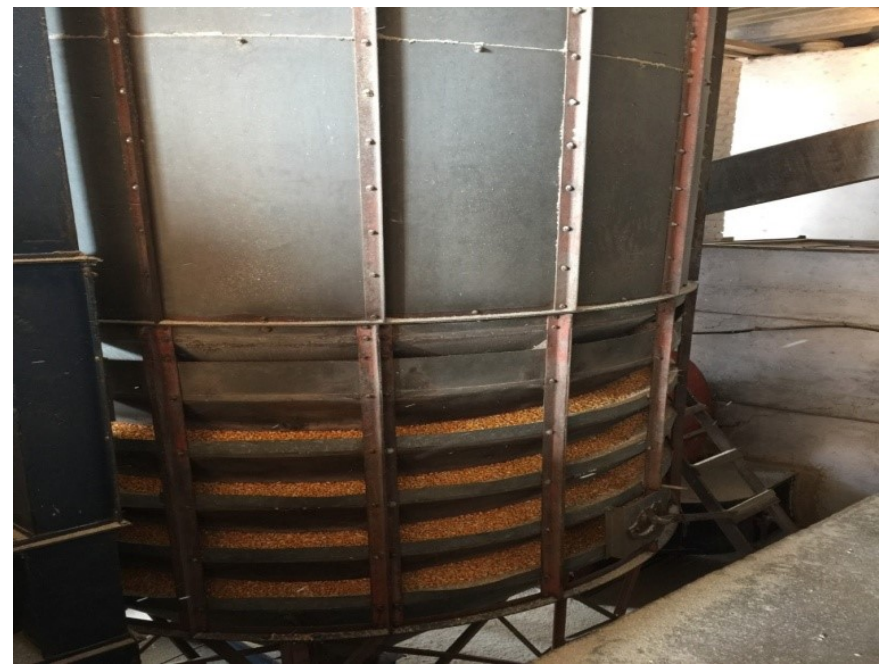

Fonte: Foto tirada pelo autor

Figura 7. Galpão de produtos ensacados para seguir para a distribuição

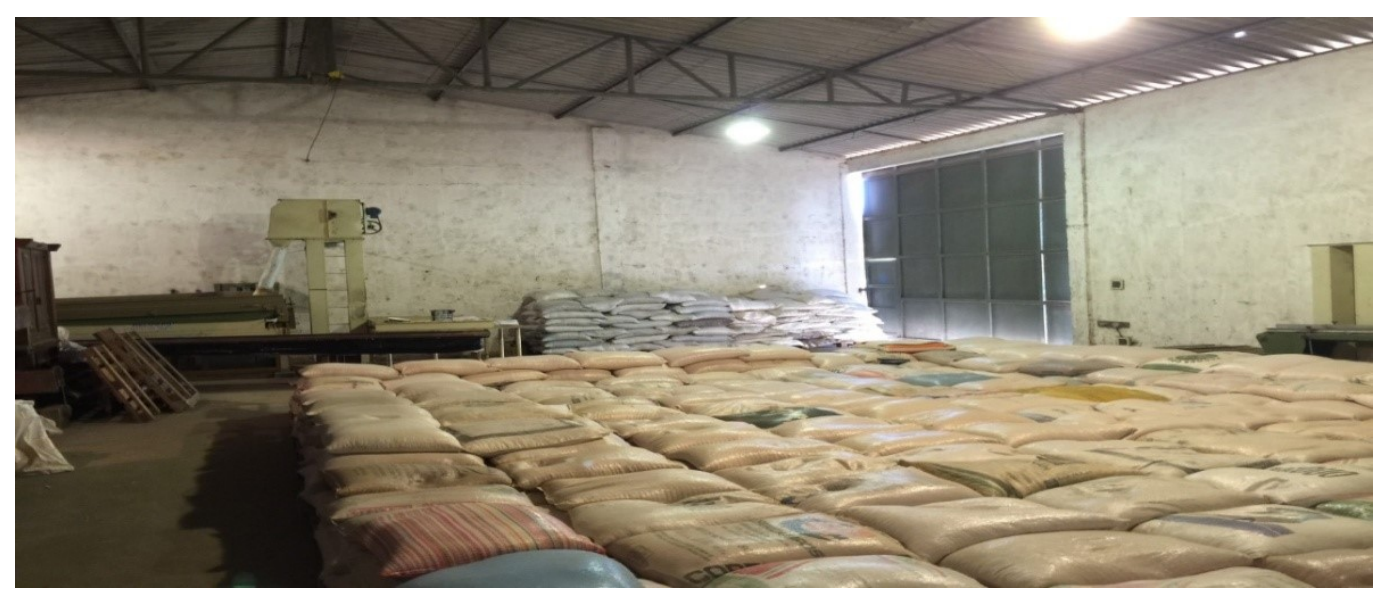

Fonte: Foto tirada pelo autor 
Figura 8. Silo

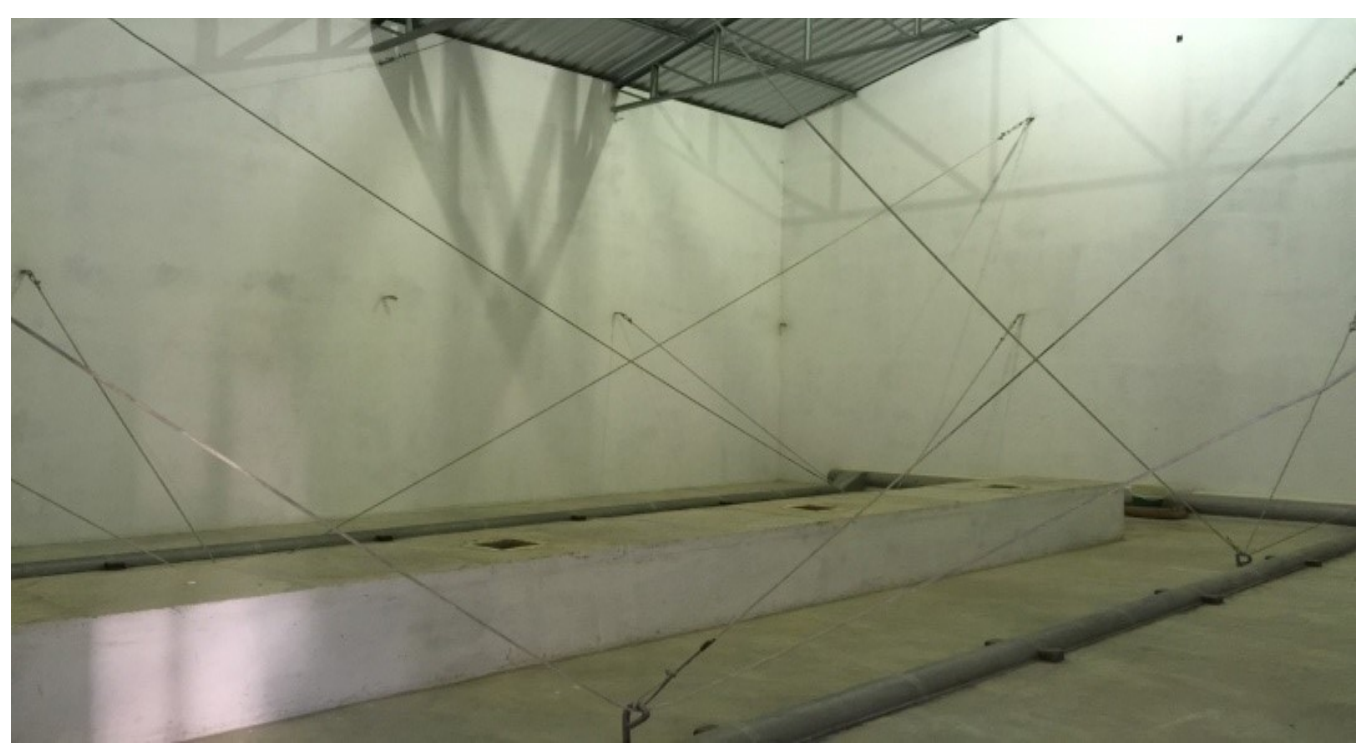

Fonte: Foto tirada pelo autor

\subsection{Descrição e análise dos resultados}

\subsubsection{Armazenagem e Escoamento}

A armazenagem, como uma das principais questões a ser considerada em logística, foi um ponto muito bem solucionado pela Fazenda, um exemplo disso foi a recente construção do Silo, que permitiu estocar um grande volume de produtos com segurança.

Depois da colheita dos produtos, os mesmos seguem para o "secador" onde são aquecidos até atingirem a umidade adequada do grão - ilustrado na foto da Figura 6. A partir daí os grãos ou são ensacados para distribuição ou são armazenados no silo a granel. Todo este processo operacional é muito bem conduzido pelos funcionários, com o máximo de cuidado no seu manuseio, assim como no ensacamento para que não haja nenhuma perda.

O silo tem que ser higienizado antes da estocagem dos grãos e, também, depois de sua distribuição para poder receber outros produtos.

Além do silo, há outro local de armazenagem, que é a estufa climatizada, voltada especialmente para as sementes de feijão produzidas na Fazenda que possui certificação para essa atividade. A estufa é uma instalação especialmente construída que permite temperatura e umidade controladas para que as sementes nela armazenadas não venham a ter fungos e insetos, ocasionando danos e, consequentemente, a perda das sementes. Depois de colhidas, as sementes são secadas para atingir a umidade ideal de armazenamento, seguindo para o ensacamento e posteriormente a estufa. 
O compartilhamento do silo com outros produtores rurais foi sugerido para o Gestor da Fazenda, porém o mesmo afirmou que não seria necessário pelo fato de existir uma alta demanda pelos produtos. Além disso, os produtores rurais próximos possuem os seus próprios silos. A Fazenda ainda possui um galpão onde os produtos ensacados ficam estocados para agilizar seu embarque nos caminhões, conforme mostra a foto da Figura 7.

\subsubsection{Transporte de produtos}

A Fazenda possui equipamentos de transporte próprio como: vagões graneleiros para transportes internos dos produtos e, também, pequenos caminhões para serviços de manutenção e compra de insumos, o que significa que ela investiu neles e assumiu seus custos diretos e indiretos inerentes à atividade, já que os próprios clientes se encarregam de transportar os produtos em seus respectivos caminhões para serem comercializados em outros locais. Este fato se deve ao fator localização da Fazenda, situada ao lado da Rodovia BR 101.

Por outro lado, a localização da fazenda também favorece os clientes, que aproveitam o "frete de retorno" de caminhões que trafegam pela Rodovia. Esta estratégia significa que eles, os clientes, usam serviços de transporte de terceiros e também conseguiram otimizar os seus custos de transporte da fazenda ao mercado consumidor, tornando-se essa solução mais uma vantagem competitiva a seu favor.

Em um País onde as rodovias são mais numerosas que as ferrovias e hidrovias, surgem problemas como elevação do preço do frete e de manutenção dos veículos. Caso os veículos enfrentem alguma condição não muito favorável das estradas fluminenses, há maior possibilidade de causar danos aos mesmos, como ter que trocar alguma peça, por exemplo, ou sofrer algum acidente. Isto junto com a alta do diesel irá refletir no preço do frete a ser cobrado. Levando em consideração o fato da Fazenda não possuir transporte para distribuição, ela não necessita preocupar-se com estes problemas, a não ser na fase de suprimento de insumos para a produção, quando usa veículo próprio, o que mostra que ela está focada apenas no seu core-business, a produção agrícola e seu armazenamento, deixando a seus clientes os problemas de distribuição para o mercado consumidor.

Assim, a Fazenda Ilha da Saudade não possui nenhum custo de frete de distribuição de seus produtos para o mercado consumidor, mas apenas de armazenamento, pois seu contrato de venda é do tipo FOB, ou seja, sua 
responsabilidade com a venda do produto cessa quando o produto vendido é embarcado no veículo de transporte contratado pelo cliente, operação essa feita com total segurança nas instalações de armazenagem da Fazenda.

Por outro lado, se a Fazenda desejar crescer futuramente em termos de auferir mais vantagem econômica, terá que investir mais na área de distribuição de produtos - armazenagem e transporte - para comercializar diretamente aos consumidores de "ponta" de grãos, como grandes atacadistas ou mercados, o que ampliaria o "leque" de clientes e aumentaria sua margem.

O processo implicaria em diversos custos, como por exemplo: precisaria um capital maior para investir em uma infra-estrutura de distribuição. Ela implicaria em investir em uma central de distribuição junto ao mercado consumidor e, dentro dele, a aquisição de equipamentos de ensacamento em embalagens menores, e em alguns veículos de transporte menores para transporte urbano e assumir os custos tributários, obedecendo as várias regulamentações legais a este tipo de serviço. O transporte da Fazenda para sua central de distribuição poderia ser executado de maneira similar que os seus clientes adotam atualmente, de aproveitamento do frete de retorno.

Caso o produtor rural não consiga arcar com as despesas, o ideal seria o uso de cooperativas.

Filiar-se a uma cooperativa pode ser benéfico para os produtores no sentido de fazer networking, por meio de troca de informações entre os produtores sobre os seus empreendimentos rurais, permitindo relacionar-se com quem é do mesmo ramo para acompanhar as novas tendências de mercado.

Portanto, a cooperativa também é vantajosa para os produtores de pequeno porte que querem crescer no ramo do agronegócio e obter competitividade. Além dela, há também outras alternativas que devem ser estudadas para obter melhores resultados econômicos, cortar custos e ter competitividade no mercado, como a TI, por exemplo.

\subsubsection{Tecnologia de Informação e Equipamentos}

A Tecnologia de Informação é um dos pontos cruciais da logística. No caso, da Fazenda llha da Saudade, ela é encontrada na colheitadeira e no uso de meteorologia por parte do Gestor da Fazenda. Também é usada para fazer a análise do solo da Fazenda, identificando os locais mais férteis e propícios para o plantio.

Porém, a Fazenda não necessita da implantação de $\mathrm{TI}$ em suas operações logísticas, pois com o que já tem é possível manter a alta 
competitividade. Portanto, caso ela queira aderir esta tecnologia para o seu auxílio, ela teria os custos financeiros de implantação e manutenção, mas, por outro lado, aumentaria a sua competitividade no mercado local.

\subsubsection{Considerações}

Ao analisar o caso da Fazenda Ilha da Saudade em Macaé, pode-se perceber que a mesma é um caso à parte dos produtores rurais do Estado do Rio de Janeiro, pois o empreendimento segue um modelo de agronegócio adequado ao contexto atual do Estado por diversas razões.

Primeiro porque ela possui uma localização excelente, do lado da Rodovia BR 101, fazendo com que ela seja mais "visível" aos clientes deste mercado e, ao mesmo tempo, estando ao lado do Rio Macaé, pode utilizar a água do rio para a irrigação da plantação, tornando o solo da Fazenda mais produtivo e diminuindo os possíveis problemas climáticos, como a estiagem.

Por outro lado, há um viés negativo nesta localização: a mesma visibilidade permitida aos clientes, simultaneamente, também pode se tornar alvo fácil dos ladrões, já que o roubo de cargas agrícolas está aumentando, com a diminuição de cargas de produtos industrializados, em virtude da crise econômica por que passa o País, requerendo cuidados especiais na área de segurança da Fazenda. A Fazenda deve investir em Tecnologia de Informação e segurança para prevenir estes roubos/furtos de produtos. Este é o maior problema enfrentado pela Fazenda, segundo o Gestor da Fazenda.

Segundo porque a Fazenda não precisa de transporte para distribuir sua mercadoria, já que está do lado da Rodovia e os clientes assumem os custos de transporte dos produtos comprados da Fazenda para serem comercializados em outro local. Caso queira aumentar a lucratividade da Fazenda, deveria ter o próprio frete voltado para a entrega aos consumidores de "ponta" (mercados e atacadistas) - como foi sugerido no item 4.2.2.

Por outro lado, em termos de melhoria dos processos internos de produção agrícola e processamento de seus produtos, há necessidade de equipamentos adequados de uso esporádico. No entanto, apesar de sua utilidade e necessidade, enfrentariam os períodos de entressafra e pousio, quando eles ficariam ociosos. Para diminuir o custo dessa ociosidade, a Fazenda poderia fazer parceria com outra fazenda próxima na sua compra, diminuindo o capital a investir.

Do ponto de vista de expansão futura da Fazenda, ela precisa ter uma visão mais ampla, pois refletindo sobre a entrevista pessoal com o Gestor, a 
única preocupação é com a segurança da Fazenda, e isso pode ser uma visão pessoal e mostra uma certa acomodação com o negócio gerido por ele, já que ele considera que a maneira que se desenvolve a Fazenda está satisfatório e não necessita mudanças nem modernização. Mas se a visão for de um grande empresário certamente ele pensaria em fazer chegar o produto junto ao mercado para eliminar intermediários entre ele e o mercado consumidor.

Para isso teria que repensar o processo logístico de distribuição dos produtos, para o aumento da lucratividade e crescimento de seu empreendimento como um todo. Caso haja capital próprio para investir em uma logística de distribuição mais arrojada, certamente o gestor deve seguir essa linha para que o produto chegue diretamente ao mercado consumidor, sem intermediários, conseguindo ao mesmo tempo maior lucratividade e, ainda, um preço final mais acessível para o consumidor final. Isto requer investir também em uma central de distribuição junto ao mercado consumidor e uma frota de veículos mais leves para a distribuição urbana.

No caso de indispor desse capital, poder-se-ia pensar em uma cooperativa de distribuição, compartilhando-se custos com seus associados e que funcionariam nos moldes do que se conceitua no Referencial Teórico. 


\section{Conclusões e recomendações para novos estudos}

A Fazenda da Ilha da Saudade tem localização privilegiada (fronteira com rio e rodovia), o que faz com que não precise de veículos para transportar os produtos para serem comercializados, já que os próprios clientes buscam a mercadoria dentro da Fazenda. Assim, sua preocupação no momento se prende ao processo de suprimentos de insumos, ao processo produtivo e aos cuidados referentes ao armazenamento do produto colhido até o seu processo de comercialização tipo FOB (FreeonBoard), ou seja, sua responsabilidade comercial cessa quando se coloca o produto agrícola no veículo do consumidor (de terceiro ou próprio). Neste caso, conclui-se pela importância da escolha da localização na logística de implantação do agronegócio.

Com relação ao processo de armazenamento interno e seus cuidados, conclui-se não haver nenhum problema adicional, a não ser a necessidade de aumentar a segurança em termos de roubo, uma vez que essa mesma localização, vantajosa para o processo de comercialização de seus produtos, torna-se vulnerável em termos de sua visibilidade, podendo ser escolhida por assaltantes, lembrando que a crise por que passa o País, em particular o Estado do Rio de Janeiro, pode acarretar um aumento de violência.

Porém, a Fazenda se mostrou acomodada ao apenas "depender" do transporte dos seus clientes e não planejando a expansão do seu negócio, visando outros públicos alvo. Se ela deseja obter mais lucratividade, certamente terá que pensar sobre esta idéia de ampliação do seu core business, o que também acarretaria em outros custos e despesas a serem acrescentadas para atender a demanda, mas através deste investimento por parte da companhia, a Fazenda poderia vender diretamente para mercados e atacadistas, eliminando intermediários, o que, consequentemente, reduz o preço final do produto, que é o objetivo do estudo.

Para que não precise adquirir frota nova para esta ampliação de distribuição física, sugere-se que a Fazenda poderia utilizar da prática de cooperativas de distribuição como alternativa para compartilhar custos nesta operação. Os ganhos são visíveis quando se analisa o agronegócio brasileiro, principalmente no estado do Rio de Janeiro, onde os produtores rurais vêem a cooperativa como uma forma de manter ou aumentar a competitividade no mercado, já que não possuem de capital financeiro para arcar com serviços próprios. Através da cooperativa, estes produtores têm um maior poder de 
negociação frente ao mercado e lucram com a economia de escala, o que resulta em um preço melhor, tanto para os produtores rurais quanto para o consumidor final. Logicamente, há que se analisar cuidadosamente esta proposta em face da legislação trabalhista, carência de mão-de-obra qualificada, altos impostos, taxas regulatórias e ofertas de infra-estrutura inadequada, que podem prejudicar a busca desta competitividade.

\subsection{Sugestões e recomendações para novos estudos}

Como desdobramentos futuros, essa linha de estudo pode ser desenvolvida através de investigação sobre a forma ideal e a real importância que o agronegócio tem para o Brasil, como uma das principais atividades econômicas do País, levando em consideração a ação do governo sobre os investimentos requisitados para alavancar o País.

Também seria interessante maior aprofundamento sobre a Tecnologia de Informação, já que é um tema relativamente recente e que pode agregar muito para o tema deste estudo.

Por fim, este estudo também poderá ser utilizado para elaboração de pesquisas posteriores que venham a enriquecer a bibliografia pouco existente sobre o assunto por se tratar de um tema que é amplo e ao mesmo tempo específico e, desta maneira, contribuir para o esclarecimento melhor dos problemas vivenciados pelos empresários do agronegócio. 


\section{Referências Bibliográficas}

- $\quad$ http://www.brasil.gov.br/governo/2013/07/transporte-ferroviario-urbano-no-riode-janeiro-recebe-investimento-de-r-1-6-bilhao - Artigo "Transporte ferroviário urbano no Rio de Janeiro recebe investimento de R $\$ 1,6$ bilhão"; com tema relacionado ao financiamento pelo BNDES junto a SuperVia, levando melhoria deste modal ao Estado do Rio de Janeiro. Site acessado no segundo semestre de 2016 .

- Revista "Valor Setorial - Logística" - Março 2016

- http://www.itaubba.com.br/portugues/palestras/pdf/logistica.pdf - Artigo "A logística do Agronegócio de hoje e seu futuro - Uma visão Global do Brasil"; com tema voltado a importância da logística para o agronegócio brasileiro, levantando fatores que impactam a redução de custo final do produto. Artigo acessado no segundo semestre de 2016.

- $\quad$ https://pt.wikipedia.org/wiki/Log\%C3\%ADstica - Artigo "Logística"; tema sobre o que significa logística, sua origem, principais fatores envolvidos e suas ferramentas. Site acessado no primeiro semestre de 2016.

- http://www.ipea.gov.br/agencia/images/stories/PDFs/160311 orair 2016031 $\underline{0 . p d f}$ - Artigo "Planejamento e Execução do Investimento em Infraestrutura"; Tema "Investimento público no Brasil: trajetória recente e relações com o regime fiscal. Artigo acessado no segundo semestre de 2016.

- $\quad$ http://www.armlogistica.com.br/armazenagem-e-estocagem-entenda-asdiferencas-de-uma-vez-por-todas/ - Artigo "Armazenagem e estocagem: entenda as diferenças de uma vez por todas"; Tema: conceitos sobre armazenagem e estocagem, suas comparações e vantagens. Site acessado no segundo semestre de 2016.

- http://www.infowester.com/ti.php - Artigo "O que é Tecnologia da Informação (TI)?"; com o tema voltado ao que é a TI, uma breve introdução e história. Site acessado no segundo semestre de 2016. 
- http://guiadoestudante.abril.com.br/profissoes/gestao-da-tecnologia-dainformacaol - Artigo "Gestão da Tecnologia da Informação; com tema voltado ao que um profissional de TI faz e como que o mercado está hoje. Site acessado no segundo semestre de 2016.

- BALLOU, Ronald H. "Logística Empresarial", Editora Atlas (1993)

- BOWERSOX, Donald J.; CLOSS, David J.; COOPER, M. Bixby "Logística Empresarial - O processo de integração da cadeia de suprimento", Editora Atlas (2007)

- https://www.portaleducacao.com.br/administracao/artigos/31564/distribuicaofisica-logistica-empresarial - Artigo "Distribuição Física - Logística Empresarial"; Tema: O que são centros de distribuição e distribuição física, no que ela consiste e o fluxo/processo que ela segue.

- https://www.sebrae.com.br/sites/PortalSebrae/bis/cooperativa-o-que-e-paraque-serve-como-funciona, 7e519bda15617410VgnVCM2000003c74010aRCRD - Artigo "Cooperativa: o que é, para que serve, como funciona"; Tema: definição de cooperativa, os princípios e os ramos do cooperativismo, como funcionam as cooperativas e como são criadas. Artigo acessado no segundo semestre de 2016.

- http://www.canalrural.com.br/noticias/guias-e-servicos/conheca-passos-paracriacao-uma-cooperativa-37284 - Artigo "Conheça os passos para a criação de uma cooperativa"; tema que leva em consideração o passo a passo para criação de uma cooperativa, assim como suas legislações. Artigo acessado no segundo semestre de 2016.

- VERGARA, Sylvia Constant - "Projetos e Relatórios de Pesquisa em Administração", Editora Atlas 6a edição - (2005)

- http://ruralcentro.uol.com.br/noticias/eficiencia-na-armazenagem-pode-garantirlucro-para-produtores-rurais-57790 - Artigo "Eficiência na armazenagem pode garantir lucro para produtores rurais"; tema que aborda o quão importante a armazenagem é. Site acessado no segundo semestre de 2016. 
- $\quad$ http://www.headlogistica.com.br/logistica-e-tecnologia-a-equacao-perfeita-parao-e-commerce/ - Artigo "Logística e Tecnologia: a equação perfeita para o ecommerce". Mostra como tema: o papel fundamental da TI utilizada em conjunto com a logística. Site acessado no segundo semestre de 2016.

- $\quad$ http://www.ufrgs.br/cursopgdr/downloadsSerie/derad005.pdf - Artigo "Métodos de Pesquisa"; com tema aos seus conceitos básicos, à pesquisa científica, à estrutura do projeto de pesquisa e à construção da mesma. Artigo acessado no segundo semestre de 2016.

- http://marketingfuturo.com/entrevistas-de-profundidade-o-que-e-e-como-fazer/ Artigo "Entrevista em profundidade - O que é e como fazer?"; tema o qual aborda citações bibliográficas a respeito do conceito e como que se realiza uma "entrevista em profundidade". Site acessado no segundo semestre de 2016.

- http://agenciaspostais.com.br/?page id=6895 - Artigo "Agências Ferroviárias"; Tema: este artigo fala sobre todas as estradas de ferro do Estado do Rio de Janeiro, abordando sua história e como está hoje. Artigo acessado no segundo semestre de 2016.

- Revista Exame - Infraestrutura: 20 anos para tirar o atraso, Editora Abril (2016) 


\section{Apêndice 1:}

\section{Roteiro de Entrevista}

\section{Entrevistado: Sérvulo Marton}

- $\quad$ Idade? Possui filhos (as)?

- Qual é o seu cargo dentro da Fazenda?

- Trabalha há quanto tempo aqui? Está satisfeito?

- Quanto ao empreendimento, quantos Alqueires ou Hectares a fazenda possui?

- $\quad$ Quanto de área plantada possui e quais são os produtos?

- Quantos funcionários a Fazenda possui? Existem contratos temporários (época de safra)?

- Há algum tipo de treinamento para os funcionários?

- A infraestrutura é nova? Ou seja, foi construído recentemente, passou por reformas ou não?

- $\quad$ Possuem todos os equipamentos necessários ou acham que poderiam ou necessitam de mais?

- $\quad$ Existem parceiros agrícolas? Qual é a percentagem recebida do lucro?

- Qual a freqüência de colheita de cada produto (quantas vezes por ano/mês?

- $\quad$ Qual é o fluxo desde a colheita dos produtos até a distribuição?

- $\quad$ Faz inventário em alguma parte do processo? Quais? 
- A Fazenda possui armazém/silos? Os espaços dos mesmos estão sempre otimizados? Já alugou ou compartilhou armazém?

- Quais os principais fornecedores e clientes? E para onde escoa a maioria da produção? Exportam?

- Possuem transporte próprio ou terceirizam? Qual custo?

- Cooperativa de transporte seria uma boa alternativa? A fazenda já participou de cooperativas antes?

- Qual transporte ideal para escoar a produção? Ferrovia, Rodovia, Hidrovia?

- Há intermediários na maioria da distribuição dos produtos? Como poderia reduzir?

- A Fazenda distribui para algum consumidor final?

- Quais insumos devem ser utilizados para cada produto?

- Há armazenagem dentro dos veículos também para que os produtos fiquem mais seguros e assim, evita perdas?

- Há algum controle/supervisão nas operações logísticas do empreendimento? Gestão de estoque, monitoramento, etc.?

- $\quad$ A Fazenda utiliza da Tecnologia de Informação em suas operações? Quais? E em qual processo há certa necessidade para sua implantação?

- $\quad$ O que você acha que a Fazenda tem de vantagem competitiva sobre as outras?

- Há algum programa sustentável dentro da Fazenda? Como é?

- Quais os piores problemas e os mais comuns enfrentados pela Fazenda? 
Existe algum problema logístico que a Fazenda tem? 